\title{
Impact of ethical certifications and product involvement on consumers decision to purchase ethical products at price premiums in an emerging market context
}

\author{
Swetarupa Chatterjee ${ }^{1}$ Naman Sreen ${ }^{2,3}$ (D) Jyoti Rana ${ }^{4} \cdot$ Amandeep Dhir $^{5,6,7}$. \\ Pradip H. Sadarangani ${ }^{1}$
}

Received: 5 September 2020 / Accepted: 26 April 2021 / Published online: 29 November 2021

(c) The Author(s) 2021

\begin{abstract}
In emerging markets, instances of increasing consumers focus on ethical aspects of the product are observed. To this end, we aim to examine the influence of two ethical certifications and two product involvement types on consumers willingness to purchase ethical products at price premiums in the Indian market. No animal cruelty certification and no child labor certification are chosen as the ethical certifications, and a shirt and a bar of soap are chosen as high and low involvement product categories. Data is collected from 206 respondents for the experiment, in which consumers willingness to purchase a product is evaluated for different product scenarios. The results of the study indicate that individuals show highest willingness to purchase products (a shirt or a soap) when both certifications (no animal cruelty, no child labor) are present. However, in comparing individual certifications, individuals prefer no animal cruelty certification for a shirt and no child labor certification for a bar of soap. The study provides insights to practitioners regarding consumers present perception of ethical aspects in the product and directions to increase sales of ethical products in the Indian market.
\end{abstract}

Keywords Ethical certifications · No animal cruelty $\cdot$ No child labor $\cdot$ Product involvement $\cdot$ Willingness to purchase at price premium

\section{Introduction}

Ethical consumption refers to the consumption of products that are manufactured or processed without causing harm to animals and environment (Davies \& Gutsche, 2016). Furthermore, they do not involve child labour and are based on fair trade practices (Davies \& Gutsche, 2016). Media has highlighted the ethical concerns

Amandeep Dhir

amandeep.dhir@uia.no

Extended author information available on the last page of the article 
and making consumers aware about the importance of ethical consumption (Kang \& Namkung, 2018; Lu \& Sinha, 2019), leading to a rise in the consumers preference and demand for ethical products. For instance, a press release showed that around 33 percent of the consumers favour purchasing the brands which are ethical as opposed to the conventional ones (Unilever, 2017). Scholars indicate that ethical consumption has increased both in scale and scope (Bennett, 2018; Ryan \& Casidy, 2018). Furthermore, it is expected that the consumers will prefer products with ethical aspects over traditional products (Accenture, 2020). Scholars also argue that consumers not only show a favourable attitude towards brands manufacturing their products ethically, but also boycott those brands that engage in unethical practices (Lim \& Shim, 2019). Subsequently, the consumer demand has led organizations to invest in ethical products and practices (Minton et al., 2012; Peattie \& Samuel, 2018). However, despite the increase in the consumer's ethical concerns, as well as the demand and availability for ethical products, the market for ethical products is still a niche (Kushwah et al., 2019). Recent literature suggests that consumers stated preferences for ethical products do not always convert into the actual buying behaviour (Govind et al., 2019). One prominent reason for consumers lower tendency to actually purchase/buy the ethical products is the high price premium associated with the ethical products (Gallenti et al., 2016; Gleim et al., 2013).

The prior literature suggests that there are several experimental studies to measure the consumer willingness to purchase ethical products at a price premium (Park, 2018). However, these studies have certain limitations. First, existing studies have offered a base price to consumers and later ask them to provide the value of premium they would be willing to pay above that for an ethical product (Gallenti et al., 2016; Mai, 2014). Since these studies do not provide information on consumer reaction to the real price premiums in the market, organisations and brands have little idea whether consumers will actually purchase the ethical products already available in the market at certain price premiums. Second, most studies focus on evaluating the consumer's willingness to purchase ethical products for one ethical certification, such as fair-trade (Lappeman et al., 2019; Rashid \& Byun, 2018). However, the market has numerous ethical products possessing more than one ethical certification, such as Khadi Essentials, which has certifications like "no animal cruelty", "organic", and "vegan". Some scholars like Park (2018) have tested the influential role of multiple ethical certifications in their studies. However, a one to one relationship was tested and it included a single product category (Gallenti et al., 2016). Gallenti et al. (2016) tested the differences in willingness to pay for coffee with organic certification, and coffee with fair trade certification independently. They do not test consumer's willingness to purchase the product at a price premium when it has both the organic and fair-trade certifications. Multiple ethical certifications may increase consumer's trust regarding the authenticity of the ethical claims and thereby, may increase consumer's willingness to purchase a product at price premiums. Because of the lack of literature on the willingness of customers to purchase a product of high price with numerous ethical certifications, practitioners do not have much idea whether they should acquire multiple ethical certifications for their products at an additional cost. Additionally, the literature shows that consumer reaction towards a particular ethical dimension also depends upon the type of the product chosen for the study (Auger \& 
Devinney, 2007). For example, Basgoze (2012) found that the US consumers showed higher willingness to pay a premium for high involvement product categories than for low involvement everyday purchases. Nevertheless, the literature has rarely empirically tested whether consumer willingness to purchase ethical products will differ according to the types of product involvement (Foti \& Devine, 2019). Thereby, there is a need to study consumers willingness to purchase a product of high price that possesses multiple ethical certifications, besides examining differences in willingness to purchase a product of high price across product category involvement types. Lastly, most existing studies were conducted in the developed market context, such as US (Yacout \& Vitell, 2018) and Europe (Wiederhold \& Martinez, 2018). Studies pertaining to ethical consumerism in developing countries are sparse (Lappeman et al., 2019). Literature ignores the perspectives of consumers in developing economies regarding issues such as child labour and animal cruelty. These aspects may be viewed differently in a developing market because majority of the population have a low income; which may further threaten their livelihood opportunities. Additionally, scholars have argued that the preferences for ethical products may vary across cultures (Jung et al., 2016). Thereby, this study tests consumers reaction in a developing market context.

The current study aims to address the aforementioned gaps in the prior literature. The current study provides various product scenarios to respondents which comprised of two ethical certifications (no animal cruelty certification and no child labor certification) and two product category involvement types (highinvolvement and low-involvement). In the study, we tested consumer willingness to purchase products of high price for two ethical certifications, and two product involvement types. Two main research questions (RQs) of this study are: RQ1. Do consumers report willingness to purchase products at a price premium with the introduction of ethical certifications in the product? RQ2. Does willingness to purchase products with ethical certifications at a price premium depend upon the product involvement types? In the current study, India was chosen as the study context because the demand for the ethical products is surging within India with more than $60 \%$ of shoppers seeking ethical characteristics in their products (Bhushan, 2019). Companies are also reporting that their ethical products are growing at a faster pace than conventional products. We also wanted to address the gap related to the overemphasis on developed markets in prior literature. Additionally, Indian market is lucrative for the organizations, as it ranks as the fifth-largest economy globally, ahead of UK and France (Economic Times, 2020). Therefore, studying Indian consumers can have significant repercussions for the whole world.

The rest of the article is structured as follows. First, Sect. 2 presents the literature review and the hypotheses of this study. Sect. 3 provides the details of the variables chosen for the study. Sect. 4 provides the methodology to illustrate the research design, the demographics of the respondents and the data collection. Sect. 5 is data analysis aiming to test and present the findings of the study. Sect. 6 presents the discussion and implications for discussing the academic and practical implications that could be derived from the study. Finally, limitations and future research is discussed in Sect. 7. 


\section{Theory development}

\subsection{Price and ethical certifications}

Price is defined as the exchange value (in currency) of the goods being traded (Smith, 2019) and was found to be an essential parameter impacting consumer willingness to buy products. However, with growing income and awareness, consumers convey that price is not the only criterion that impacts their decision to buy products, but also the environmental and societal factors associated with the product (Kang \& Namkung, 2018; Lu \& Sinha, 2019). To this end, ethical certifications provide evidence to consumers regarding the environmental or societal stance taken by the organisation whose products consumers are purchasing (Didier \& Lucie, 2008; Loureiro \& Lotade, 2005). An organisation has to follow strict regulations and standards for its entire supply chain for ensuring that the ethical stance promoted by the organisation is not a hoax (Simangunsong et al., 2016). However, ethical certifications can be obtained without following the strict standards as no clear guidelines are available (Nuttavuthisit \& Thøgersen, 2017). This makes it difficult for the consumer to trace the processes a product has gone through and ensure the credibility of the ethical claims made by the firm.

In spite of the aforementioned, literature points out that consumers usually react positively to ethical certifications by showing a higher willingness to pay for products with ethical characteristics. For example, Araque-Padilla et al. (2015) mentioned that the negative effect of price on purchasing intentions of ethical products can be attenuated by focusing on ethical characteristics. Gallenti et al. (2016) found that consumers are willing to pay a premium for coffee having ethical certification of fair trade and organic. Mai (2014) found that consumers report willingness to pay premium for a product with ethical characteristics, such as organic, recyclable packaging, and fair trade. However, previous scholars have included ethical certifications such as fair trade and organic (Konuk, 2019; Maaya et al., 2018). These certifications are associated with multiple ethical issues, for example, fair trade certification includes issues pertaining to environmental safety, labour safety, and animal protection (Rashid \& Byun, 2018; Cosmina et. al., 2016). Consumer reactions to each ethical issue may vary. A certification dealing with multiple ethical issues make it difficult to examine consumer's reaction to independent ethical issues. Hence, this study includes specific ethical issues of "no animal cruelty" and "no child labour".

\subsubsection{No animal cruelty certification}

Animals have been treated as an alternative to machines as per the need of the humans. This points at the fact that human beings were of the opinion that animals were incapable of feeling pain or pleasure (Cottingham, 1978). In the recent past, it has been proven scientifically that animals also exhibit cognition process and feel pleasure and pain (Erdenk, 2013). This has further led to the utilitarian 
philosophy, wherein an individual aims to seek pleasure only if it has not caused any pain or harm to themself or others in the society (Napolitano et al., 2010). For instance, a utilitarian individual will not accept any product which has caused pain to another human or a non-human animal.

Consumers are increasingly showing interest in activities which promote animal safety. One of the ways to ensure animal safety is through the consumption of products which promote animal safety and well-being (Cembalo et al., 2016). Companies use certifications, such as "no animal cruelty" to gain popularity among masses. However, there is a lack of strict and standardised guidelines in availing the certificate. For example, the US FDA shares the pitfalls of using the terms "cruelty free" or "no animal testing". Due to a lack of standardised definition, some companies get their final product certified by certification agencies. However, the supply chain contains members who practice animal testing. Thus, it may cause doubt in the minds of consumers.

Literature points out that products associated with animal welfare increases consumer likeness for these products and hence, consumers are willing to purchase these products at a price premium (Miranda-de la Lama et al., 2019). For example, Dransfield et al. (2005) found that consumers are willing to pay a higher price for meat when an animal is raised outdoors rather than indoors or caged. Similarly, Swanson and Mench (2000) found that in the US, consumers are willing to pay an increment for animals raised humanely. Additionally, a study by European Commission (2005) showed consumer willingness to pay more for eggs produced through an animal-friendly way.

However, most of this literature has been performed in a developed market and recently, a meta-analysis of consumer attitude towards animal welfare products show that results vary across regions (Clark et al., 2017). Developed markets have made strict rules and regulations for animal welfare and certifications. For example, the US now considers animal cruelty as a federal crime and imposes an imprisonment of up to 7 years (Gonzales, 2019). However, in India, the focus has been on economic growth and care for animals has taken a backward seat. For instance, the animal prevention law in India was legislated in 1960 and since then no amendments have been made to it. According to this law, punishment imposed includes a maximum fine of Rs. 50 (less than a dollar) (Yuvraj, 2020). Such a low fine fails to provide a message that a person who partakes in animal cruelty will face severe consequences. Nevertheless, recent news articles who have reported against animal cruelty have raised awareness regarding animal protection in India. For instance, a recent incident of a pregnant elephant that died because she was fed crackers has raised animal concerns all over India (The Economic Times, 2020). Additionally, Indian culture has always been a man-nature harmonious culture in which few gods exist in the form of animals (Sreen et al., 2018).

With the growing concern about animal welfare, many products with a certification for "no animal cruelty" have been launched in the Indian market. Various organisations, such as those from Body Shop India or Forest Essentials India are gaining acceptance among the Indian consumers. However, there is a lack of research to show if individuals are willing to pay premium for such products in the Indian context. With this background, we propose the hypothesis: 
$\mathrm{H}(1)$ : Consumers report higher willingness to purchase products at price premiums when they have 'no animal cruelty certification' than when they do not have 'no animal cruelty certification'

\subsubsection{No child labour certification}

Child labour poses various threats to child protection. Child labour may hamper a child's right to education (Kennedy, 2019). As a result, a child will not gain a skill set to obtain good employment opportunities throughout his/her life. Additionally, child labour threatens a child's physical and mental development due to unsafe working conditions (International Labor Rights Forum, 2011).

Awareness of these conditions has led various consumers to demand for no child labour certification in their products (Folkes \& Kamins, 1999). For example, various organisations have been established that focus on providing no child labour certifications (Baland \& Duprez, 2009). However, like no animal cruelty certification, these organisations have also raised concerns that they could not fully ensure that no child labour has been employed. These organisations do indicate that they can put in practices through which they can minimize child labour. It is also worthwhile to note that while no child labour is promoted in developed economies, developing economies may possess a varied take on this issue (Maya Jariego, 2017).

Majority of the population in developing economies is poor and under such financial constraints the whole family, including the children work for a livelihood. When no child labour restrictions are imposed by international firms, it may further increase the risk of exploitation of children (Boje \& Khan, 2009).

Child labour has become a kind of norm in developing economies (Kennedy, 2019). In fact, most people believe that child labour is an act of altruism as it helps the poor family to earn. This raises concern as to whether a no child labour certification would result in promoting ethical products or will have no effect at all in a developing market context. However, resonating with previous scholars showing consumers higher willingness to pay premiums for products with ethical certifications, we raise the hypothesis:

$\mathrm{H}(2)$ : Consumers report higher willingness to purchase products at price premiums when they have 'no child labour certification' than when they do not have 'no child labour certification'

\subsubsection{No animal cruelty certification and no child labour certification}

Past studies have majorly looked into various ethical certifications and their impact on the consumer's willingness to pay a premium (Wang et al., 2019). However, previous scholars examine the preference of consumers for one certification over the other (Hainmueller et al., 2015). Bissinger and Leufkens (2017) studied consumer's willingness to pay a premium for organic and fair trade coffee, and reported that fair trade label is preferred over organic label. Also, Rousseau (2015) found out that consumers prefer fair trade chocolate as compared to organic chocolate. Previous scholars have reported inconsistent findings related to consumers reaction towards 
multiple certifications in a product. For example, Didier and Lucie (2008), through their study, showed that for a product with more than one ethical certification, the intention remains the same or may also decrease, as compared to the individual certifications. On the other hand, Perrini et al. (2009) mention that multiple social activities from a firm enhance consumer's intentions. He found that organizations selling fair trade plus doing CSR created a positive intention of consumers to buy fair trade products. On similar lines, we propose that there will be a higher intention to buy a product sold at premium with two certifications as compared to a single certification or no certification. Therefore, we hypothesize the following:

$\mathrm{H}(3)$ : Consumers report higher willingness to purchase products at price premiums when they have both 'no animal cruelty certification' and 'no child labour certification' than when they either have any one or none of them

\subsection{Product involvement types}

The term involvement begins from a psychology study that defined the word as a subconscious or conscious state relating a stimulus to a person's ego (Sherif \& Cantril, 1947). Initial research by Houston and Rotschild (1978) indicated that involvement constitutes two types, which are enduring and situational involvement. Enduring is a permanent concern related to an object, whereas situational is a temporary concern related to an object raised due to a certain situation, for example: buying a wine bottle, since your boss is coming to your house. Involvement may vary according to the object under observation. The objects under observation can be advertisement, activity, issue, product and brand.

In 1985, a number of scholars studied the construct involvement. Zaichkowsky (1985) developed a one-dimensional construct of involvement that Laurent and Kapferer (1985) refuted by stating that involvement is a multifaceted construct consisting of hedonic value, sign value, risk probability, risk impact, and importance. Laurent and Kapferer (1985) are criticized by Mittal and Myung-Soo (1988) as they point out that except for importance, other facets are not facets but antecedents. To this end, Mittal (1995) states that involvement can be because of the product or because of the purchase decision.

Similarly, involvement related to ethical consumption may be because of the product itself or the ethical aspect. We follow Tarkiainen and Sundqvist (2009) to examine involvement as this study is similar to their study in which they aim to determine differences in the consumers choice of a product with organic characteristics and one without. Tarkiainen and Sundqvist (2009) include a measure of productcategory involvement, which is defined as importance consumers place on choosing a good product. Hence, in this paper whenever we refer to the term involvement, we mean product category involvement which is also a part of purchase involvement defined by Mittal (1989).

Involvement sustains perception about the significance of the product category in line with consumer interests, needs, and values (Belanche et al., 2017). Product involvement contributes to consumer decision making and explains variability in consumer behaviour (Dholakia, 1998). 
Two involvement types emerge, namely high-involvement products and lowinvolvement products. The difference in involvement types depends on the extent of consumers search, evaluation, and cognitive efforts during the choice process (Cowan \& Ketron, 2019). Since ethical products belong to both involvement types, consumer willingness to pay a premium for ethical products may vary across the two involvement types. For a high-involvement type, consumers exert applications in search and evaluation, whereas for a low-involvement type, consumers neither wish nor put extra search and evaluation efforts (Bian \& Moutinho, 2011). This study includes shirt as a high involvement product category type and a bar of soap as a low involvement product category type.

\subsubsection{High involvement product category type: Shirt}

High-involvement products possess a high price and represent consumer lifestyle, status, and personality (Gadhavi \& Sahni, 2020; Lertwannawit \& Mandhachitara, 2012). Clothing resembles these traits and hence, a shirt is chosen as a high-involvement product category.

Additionally, the fashion industry has come into the spotlight for following unethical practices, such as polluting the environment, exploiting human labour and promoting a materialistic lifestyle (Taplin, 2014; Bostrom \& Micheletti, 2016; Dahlbo et al., 2017). Fashion is considered a fad and the demand for fashion products is ever-growing (Bandyopadhyay \& Ray, 2020). To keep up with the pace in demand, few companies adopt unethical practices to reduce labour cost by hiring child labourers, procuring cheap raw materials, and promoting just-in-time production by sacrificing labour safety (Smestad, 2009).

As people gain awareness regarding these issues, they have started raising their voices against companies that follow such unethical practices. Various social organisations have also taken a stance against these unethical practices. For example, People for the Ethical Treatment of Animals (PETA) promotes no animal cruelty and their fashion revolution campaign stands against poor working conditions (Roloff, 2018).

Consumer boycotts and protests have led various fashion-related companies to report information regarding their product's environmental and societal aspects (Di Benedetto, 2017; Vehmas et al., 2018). Reporting the ethical stances taken by the organisation has a positive influence on consumer propensity to purchase products (Henninger et al., 2016). A recent article shows that an Indian fashion brand named Upasana benefitted by positioning ethical aspects of its products (Bandyopadhyay \& Ray, 2020). As reporting ethical aspects of the product are becoming commonplace in India, we aim to examine whether consumers would promote the ethical aspects of a shirt by showing higher willingness to pay a premium for it. We believe that as shirt is a high-involvement product category, thereby, consumers will pay close attention to all the attributes and hence, ethical attributes, such as 'no animal cruelty' and 'no child labour' certifications will influence consumer willingness to purchase a shirt at a price premium. 


\subsubsection{Low involvement product category type: Soap}

Low involvement represents a day-to-day purchase decision (Kassarjian, 1981) and hence, a bar of soap is chosen as a low-involvement product category. Cosmetics industry have come under light due to its unethical practices. For example, a number of ethical issues, such as animal cruelty, use of chemical ingredients and environmental issues have emerged in the cosmetics industry (Chun, 2016).

While literature has included daily household products, such as food and wine, little has it explored consumer willingness to pay premium for soaps possessing ethical characteristics. Soap may contain multiple ingredients that have an impact on human and environmental health (Kalyvas et al., 2014). Recently scholars have included soaps to test consumer willingness to pay premiums for different product characteristics. One such study is conducted by Yao et al. (2019) who found that consumers in New Zealand are willing to buy liquid soaps at a price premium that possess characteristics of environmental friendliness. Similarly, Auger and Devinney (2007) included a bar of soap in their study in the US and found that across various ethical issues there were no significant differences reported in willingness to pay for a bar of soap. The literature is not only limited, since it includes a bar of soap as a product category, but also provides contradictory results as noted in the above two studies. This calls for more research on this product category to examine consumer willingness to pay premium. Therefore, we choose a bar of soap as a low-involvement product type in this study. We believe that in the Indian context, since a bar of soap is a daily purchase item and ethical features have only recently gained attention, it is likely that people would ignore these ethical features for this habitual purchase.

\subsubsection{Hypothesis development- product involvement category types}

Ethical products possess nascency and credence properties, which makes it difficult to assure their authenticity. Thereby, attention will allow consumers to gather ethical information related to a product and hence, increase their willingness to pay a premium for a high-involvement product. Whereas while purchasing lowinvolvement goods, consumers spend a little amount of time and effort in searching and evaluating product information. Hence, most of the low-involvement purchases are habitual. The current habit of individuals may not include assessing ethical information due to the nascence and lack of awareness associated with ethical products. For instance, Tarkiainen and Sundqvist (2009) illustrated consumer unwillingness to buy organic food as food purchase is a habitual and lowinvolvement activity. Therefore, we raise the hypothesis:

$\mathrm{H}$ (4): Consumers report higher willingness to purchase at price premiums a shirt with 'no animal cruelty certification' than a soap with 'no animal cruelty certification'

$H$ (5): Consumers report higher willingness to purchase at price premiums a shirt with 'no child labour certification' than a soap with 'no child labour certification' 
$H$ (6): Consumers report higher willingness to purchase at price premiums a shirt with both 'no animal cruelty certification' and 'no child labour certification' than a soap with with both 'no animal cruelty certification' and 'no child labour certification'

\section{Methodology}

\subsection{Independent variables}

We conducted a true experiment, consisting of Post-test-Only Control group design and a factorial design was created with two ethical certifications (no animal cruelty and no child labour) each with two levels (certified/not certified), and two product involvement types (low-involvement product type: soap/ high-involvement product type: shirt), i.e. 2 (high involvement: shirt vs low involvement: soap)*2 (no animal cruelty certification (certified/Not certified))*2 (no child labour certification (certified/Not certified)) mixed factorial design with no animal cruelty certification and no child labour certification as within subject measures. We created fictious product scenarios with the treatment, i.e., the ethical certifications, and asked respondents to report their willingness to purchase the product at a price premium. In shirt condition, participants were provided options of (1) "no animal cruelty certification certified' and 'no animal cruelty certification not certified, (2) 'no child labour certification certified' and 'no child labour certification not certified', and (3) 'both no animal cruelty certification and no child labour certification certified', and 'both no animal cruelty certification and no child labour certification not certified'. Here, the group which was not given any of the treatments is the control group, i.e. where no certifications were present. While others are the experimental groups. In the bar of soap condition, participants were presented with the same conditions as the shirt condition.

\subsection{Recruitment of the participants}

Subjects were recruited from two Indian colleges and comprised of students, faculty, and staff. The condition for recruitment was that the candidate should be minimum graduate. We selected this sample because studies in past have shown that educated respondents know about environmentally friendly products and consider ethical purchasing decisions (Sreen et al., 2018). To this end, we chose participants who are at least graduate in terms of their educational qualification, and asked the following filter questions:

- What do you know about ethical consumption?

- Did you buy any ethical products? If yes, what did you buy and which certification did it have?

A total of 206 respondents took part in the study and were randomly assigned to the two treatment conditions: Shirt and A bar of Soap. Participants were not given any remuneration for participation. For the shirt condition, 75 participants participated in 
Table 1 Respondent Profile for Shirt

\begin{tabular}{lllll}
\hline Gender & Male & Female & & \\
& $20(27 \%)$ & $55(73 \%)$ & & \\
\hline Education level & Graduate & Postgraduate & Ph.D/ FPM & \\
& $21(28 \%)$ & $41(54.6 \%)$ & $13(17.3 \%)$ & \\
Family Income (Rs/Annum) & $>2.5$ lakhs & $2.5-5$ lakhs & $5-10$ lakhs & $>10$ lakhs \\
& $16(21.3 \%)$ & $18(24 \%)$ & $13(17.3 \%)$ & $28(37.3 \%)$ \\
Relationship Status & Married & Single & Divorced & \\
& $36(48 \%)$ & $38(50.6 \%)$ & $1(1.3 \%)$ & \\
\hline
\end{tabular}

The Table provides information in the form: number (percentage)

the study and for the bar of soap condition, 131 participants participated in the study. Demographic details of the respondents are presented in Table 1 and 2.

The Table provides information in the form: number (percentage)

\subsection{Selecting the price premiums}

Since, the focus of this research was to consider real price premiums in the market we adopted the price of the shirt from https://www.nonasties.in/ and the price of the bar of soap from the nearby grocery store. The price of the shirt was selected as Rs. 2500/-, which was among the highest priced shirts on the website https://www.nonasties.in/ and Rs. 60/- for a bar of soap, which was the highest price of a bar of soap in the grocery store. Fig. 1 We made sure that both these products had at least one kind of ethical certification.

\subsection{Controlling extraneous variables}

The extraneous variables were controlled as follows: (a) The situational variables were controlled in the study as it was conducted in a lab setting with all the factors such as light, sound, and room temperature, being constant for all the participants. (b) Experimenter effects were controlled by assigning person to overlook the behaviour of the researcher in the study. Also, the participants were not known to any of the researchers which helped in the mitigation of the experimenter effect. (c)Additionally, the participants recorded their responses in the lab setting where none of the researchers were present Fig. 2.

Table 2 Respondent Profile for Soap

\begin{tabular}{lllll}
\hline Gender & Male & Female & & \\
& $43(32.8 \%)$ & $88(67.2 \%)$ & & \\
\hline Education level & Graduate & Postgraduate & Ph.D/ FPM & \\
& $49(37.4 \%)$ & $63(48.1 \%)$ & $19(14.5 \%)$ & \\
Family Income (Rs/Annum) & $>2.5$ lakhs & $2.5-5$ lakhs & $5-10$ lakhs & $>10$ lakhs \\
& $30(22.9 \%)$ & $35(26.7 \%)$ & $20(15.3 \%)$ & $46(35.1 \%)$ \\
Relationship Status & Married & Single & Divorced & \\
& $64(50.4 \%)$ & $66(48.9 \%)$ & $1(0.8 \%)$ & \\
\hline
\end{tabular}




\section{No Child Labor Certification}

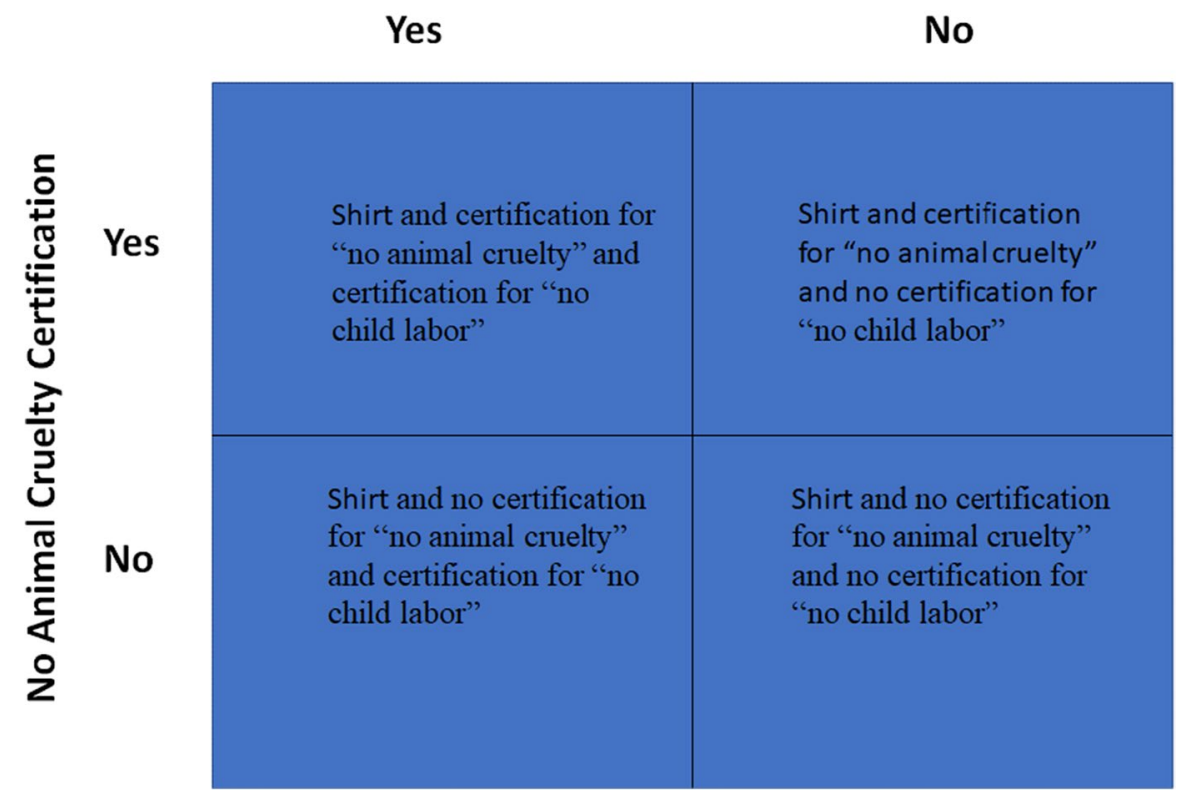

Fig. 1 Treatment conditions for shirt

\section{No Child Labor Certification}

Yes

No

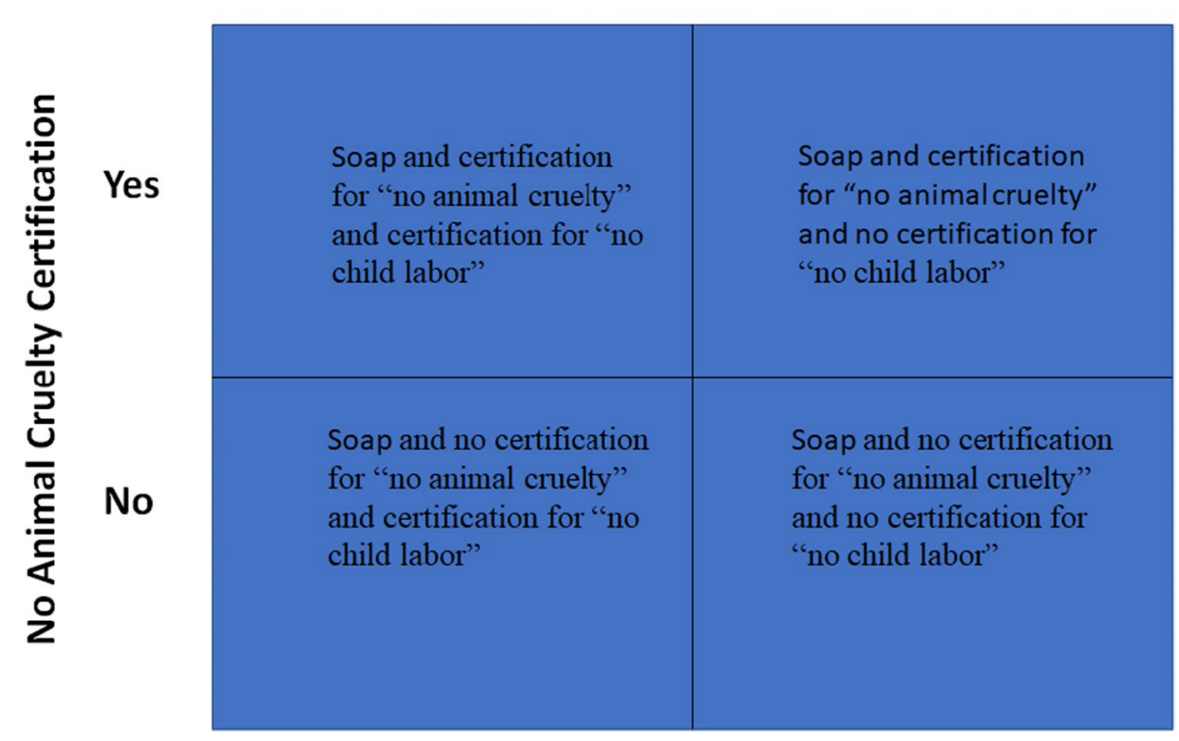

Fig. 2 Treatment conditions for soap 


\subsection{Procedure and treatment}

Participants were divided into small groups of three to six members. Participants were informed to imagine if they were in a retail outlet and making a purchase of either shirt or a bar of soap. The treatment was the product scenarios which were presented to the participants. The product scenarios were given as follows:

“A shirt costs Rs. 2500. It has been given/not been given certification for 'no animal cruelty' and given /not been given certification for 'no child labour'", OR

“A soap costs 'Rs. 60'. It has been given /not been given certification for 'no animal cruelty' and given/not given certification for 'no child labour',

Then their responses were collected for purchase intention on a five-point likert scale.

\subsection{Dependent variable}

The dependent variable for the study was purchase intention. Intention is defined as the likelihood to exhibit a certain type of behaviour (Ajzen, 1991). Purchase intention was measured through three items: (1) I intend to buy this product; (2) I intend to buy a product in the near future for myself; (3) I intend to buy this product as a gift for someone. The scale was adopted from a prior study by Schuitema and DeGroot (2015). The Cronbach alpha was 0.83, which indicates construct reliability.

\subsection{Manipulation check}

We considered a shirt as a high-involvement product type and a bar of soap as a low-involvement product type. To examine whether our assumption was correct, we performed a manipulation check by asking respondents perceptions on the item: "Choosing a good shirt or a bar of soap (product category) is a very important decision for me" (Tarkiainen \& Sundqvist, 2009). Their responses were anchored on a five-point Likert scale ranging from strongly disagree to strongly agree. The mean values for the two product types were significantly different (Mean Value: Shirt: 3.78; Mean Value-Soap: 2.35; $\mathrm{p}<0.05$ ), indicating that the consideration of products as high and low involvement category type is correct.

\subsection{Validity of the experiment}

Internal validity was ensured in various ways. First, the manipulation check was done for the independent variable and it was established that the participants of the study considered shirt as a high involvement product category type and the soap as 
a low involvement product category type. Second, randomization was used for putting the participants in the respective groups to eliminate any bias. Third, during the experiment, the conditions such as the scale, the experimenter, and the total number of participants remained constant. Fourth, no participants dropped out of the study and hence it also ensured that the study is internally valid. Fifth, the respondents were not aware of the assignment of the treatment to them, which corroborates the establishment of internal validity of the study. Last, there was no academic misconduct, thereby ensuring that the data is authentic and true to the best of the experimenter's knowledge.

The external validity of the study can be defined as the extent to which the study is generalizable to the world. Our focus was on the internal validity of the study as it was done in a controlled lab setting. However, the following were done to mitigate the threat to the external validity in the study: (a) Order effect was eliminated using the randomization while assigning the treatment to the groups. (b) The experimenter did not remain in the line of sight of the participants during the course of the study thereby ensuring the external validity. (c) To the best of the researchers' knowledge, the participants were not given any prior clue to the expected outcomes of the study or the subject being studied.

\subsection{Data analysis}

A repeated measure factorial anova was conducted to compare the main effects of no animal cruelty certification and no child labour certification, and to test differences between the product category involvement types across the certifications (H1-H6). Repeated measures anova can be used in two cases, (i) when the study is longitudinal in nature, and (ii) when the number of treatments are three or more. For this study, we used repeated measures anova owing to the second reason as mentioned above.

\section{Results}

\subsection{Impact of ethical certifications on purchasing products at a price premium}

\subsubsection{Results: Shirt}

A two-way analysis was conducted to examine the influence of two independent variables (no animal cruelty certification, no child labour certification) on an individual's willingness to purchase a shirt at a price premium. No animal cruelty certification consisted of two levels (Certified/Not Certified) and no child labour certification consisted of two levels (Certified/Not Certified). The main effect of no animal cruelty certification yielded an $\mathrm{F}$ ratio of $\mathrm{F}(1,74)=76.52, \mathrm{p}<0.001$ $\left(\eta^{\wedge} 2=0.51\right)$, indicating a significant difference in consumer willingness to purchase a shirt certified with no animal cruelty certification at a price premium versus a shirt not certified with no animal cruelty certification at a price premium 
Table 3 Mean values and standard deviation (SD) for shirt and soap

\begin{tabular}{|c|c|c|c|}
\hline Product Category & Scenarios & Mean & SD \\
\hline Shirt & $\begin{array}{l}\text { 1. No animal cruelty } \\
\text { certification present } \\
\text { 2. No animal cruelty } \\
\text { certification not } \\
\text { present } \\
\text { 3. No child labour } \\
\text { certification present } \\
\text { 4. No child labour } \\
\text { certification not } \\
\text { present }\end{array}$ & $\begin{array}{l}2.94 \\
2.15 \\
2.90 \\
2.20\end{array}$ & $\begin{array}{l}0.74 \\
0.86 \\
0.75 \\
0.86\end{array}$ \\
\hline Soap & $\begin{array}{l}\text { 1. No animal cruelty } \\
\text { certification present } \\
\text { 2. No animal cruelty } \\
\text { certification not } \\
\text { present } \\
\text { 3. No child labour } \\
\text { certification present } \\
\text { 4. No child labour } \\
\text { certification not } \\
\text { present }\end{array}$ & $\begin{array}{l}2.74 \\
2.19 \\
2.82 \\
2.12\end{array}$ & $\begin{array}{l}0.80 \\
0.80 \\
0.80 \\
0.77\end{array}$ \\
\hline
\end{tabular}

(see Table 3). Similarly, the main effect of no child labour certification yielded an $F$ ratio of $F(1,74)=55.73, p<0.001\left(\eta^{\wedge} 2=0.43\right)$, indicating a significant difference in consumer willingness to purchase a shirt certified with no child labour certification at a price premium versus a shirt not certified with no child labour certification at a price premium (See Table 3 ). The interaction effect was significant, $\mathrm{F}(1,74)=15.62, \mathrm{p}<0.001\left(\eta^{\wedge} 2=0.17\right)$.

\subsubsection{Results: Soap}

A similar two-way analysis as above was conducted to examine the influence of two independent variables (no animal cruelty certification, no child labour certification) on an individual's willingness to purchase soap at a price premium. No animal cruelty certification consisted of two levels (Certified/Not Certified) and no child labour certification consisted of two levels (Certified/Not certified). The main effect of no animal cruelty certification yielded an $\mathrm{F}$ ratio of $\mathrm{F}$ $(1,130)=47.94, p<0.001 \quad\left(\eta^{\wedge} 2=0.27\right)$, indicating a significant difference in consumer willingness to purchase a bar of soap certified with no animal cruelty certification at a price premium versus a bar of soap not certified with no animal cruelty certification at a price premium (See Table 3). Similarly, the main effect of no child labour certification yielded an $F$ ratio of $F(1,130)=89.89$, $\mathrm{p}<0.001\left(\eta^{\wedge} 2=0.41\right)$, indicating a significant difference in consumer willingness to purchase a bar of soap certified with no child labour certification at a price premium and a bar of soap not certified with no child labour certification at a price premium (See Table 3). Fig. 3 The interaction effect was significant, $\mathrm{F}(1,130)=12.79, \mathrm{p}<0.001\left(\eta^{\wedge} 2=0.09\right)$. 


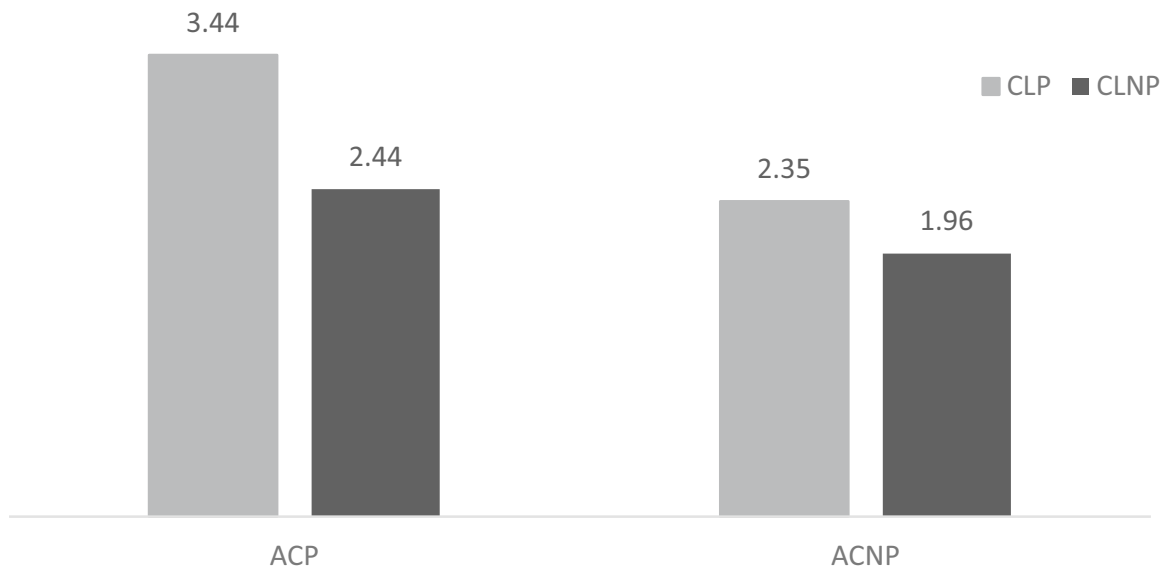

Fig. 3 Intention to buy shirt at price premium

\subsection{Differences in consumer willingness to purchase a product at premium across product category involvement types}

Product Involvement has a significant interaction effect with no animal cruelty certification for determining consumer willingness to purchase a product at a premium price, yielding an $\mathrm{F}$ ratio of $\mathrm{F}(1,205)=4.09, \mathrm{p}<0.05\left(\eta^{\wedge} 2=0.02\right)$. Table 4 Participants reported preference for no animal cruelty certification in case of both low-involvement and high-involvement products over the conditions when the no animal cruelty certifications were not present, however, the difference was greater in the case of high-involvement product category type. Fig. 4 There was no significant interaction effect between product involvement and no child labour certification $\left(\mathrm{F}(1,205)=0.00, \mathrm{p}>0.05\left(\eta^{\wedge} 2=0.00\right)\right)$ and product involvement and no child

Table 4 Table to show the main effect and the interaction effect of all the treatment groups in the study

\begin{tabular}{lccc}
\hline Main Effects (Shirt) & F-value & P-value & Partial $\eta^{\wedge} 2$ \\
\hline 1. No Animal Cruelty Certification & 76.52 & $\mathrm{P}<0.001$ & 0.51 \\
2. No Child Labour Certification & 55.73 & $\mathrm{P}<0.001$ & 0.43 \\
Interaction Effects (Shirt) & & & \\
3. No Animal Cruelty Certification* No Child Labour Certification & 15.62 & $\mathrm{P}<0.001$ & 0.17 \\
Main Effects (Soap) & & & \\
1. No Animal Cruelty Certification & 47.94 & $\mathrm{P}<0.001$ & 0.27 \\
2. No Child Labour Certification & 89.89 & $\mathrm{P}<0.001$ & 0.41 \\
Interaction Effects (Soap) & & & \\
3. No Animal Cruelty Certification* No Child Labour Certification & 12.79 & $\mathrm{P}<0.001$ & 0.09 \\
Interaction Effect (product involvement category types) & & & \\
1. Product Involvement* No Animal Cruelty Certification & 4.09 & $\mathrm{P}<0.05$ & 0.02 \\
2. Product Involvement* No Child Labour Certification & 0.00 & $\mathrm{P}>0.05$ & 0.00 \\
3. Product Involvement* No Animal Cruelty Certification* No Child & 0.18 & $\mathrm{P}>0.05$ & 0.00 \\
$\quad$ Labour Certification & & & \\
\hline
\end{tabular}




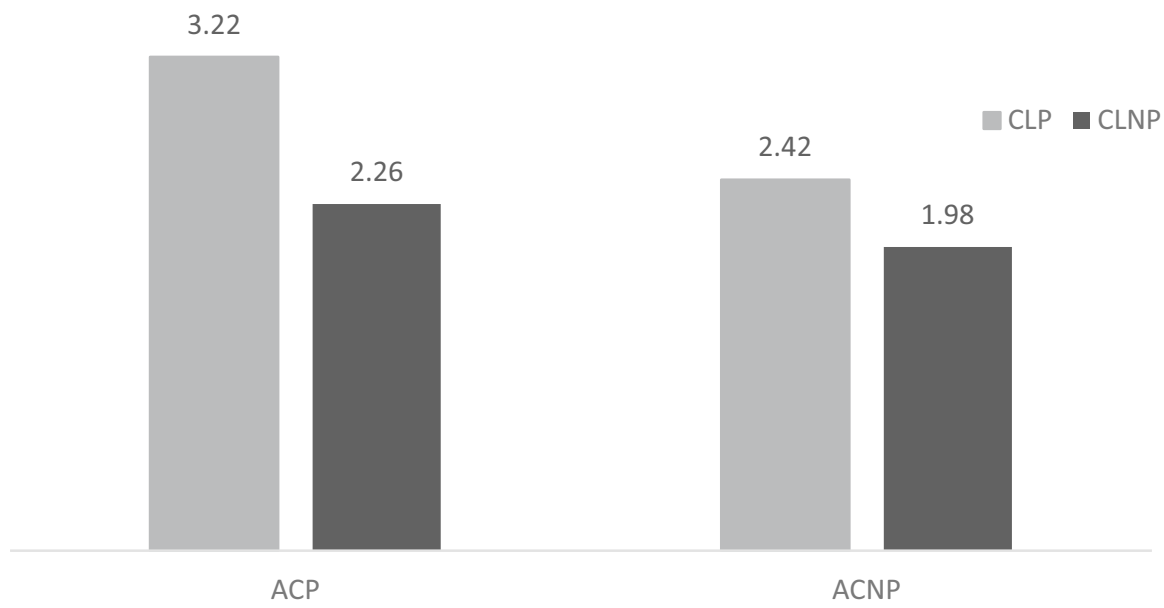

Fig. 4 Intention to buy soap at price premium

labour certification and no animal cruelty certification $(\mathrm{F}(1,205)=0.18, \mathrm{p}>0.05$ $\left.\left(\eta^{\wedge} 2=0.00\right)\right)$.

\section{Discussion and implications}

\subsection{Discussion}

$\mathrm{H}(1)$ is supported, which shows that the consumers are willing to buy products at a price premium certified for "no animal cruelty." Researchers have worked on animal welfare previously and have found that consumers are willing to pay a premium for animal welfare (Miranda-de la Lama et al., 2019). Consumers are gradually becoming concerned about the ongoing animal cruelty in various industries (Alonso et al., 2020). The issue of animal cruelty has led to widespread protests and activism in India. Companies like The Body Shop and No Nasties are slowly gaining traction in the Indian market (Retail News Asia, 2019) as consumers are becoming conscious about the impact of the choice they are making. Nonetheless, the literature lacks any such study to demonstrate the effect of "no animal cruelty" certification on consumer buying in the Indian context.

$\mathrm{H}(2)$ is supported, which means that consumers are willing to buy a product with price premium certified for "no child labour". No child labour certification is a relatively new concept in the Indian context and thus at a very nascent stage. There has been no study that uses "no child labour" certification to study consumer behaviour in India to the best of our knowledge. Studies have shown consumers in developed markets are willing to take a stand against child labour in developing markets (Hainmueller \& Hiscox, 2015; Makarem \& Jae, 2016). Our research shows that even in a developing market context, where child labour is rampantly used (Ilyas et al., 2020; Kennedy, 2019), the consumers are gaining awareness about the child exploitation 
that happens and prefer the products that do not use child labour. Various organizations such as Stop the Traffik have been instrumental in raising awareness about child labour and its drawbacks. The International Labour Organization observes a day (on June 12) to spread awareness regarding child labour every year. They are involved in activism against child labour and pledges to eliminate child labour by 2025 (International Labour Organization, 2018).

$\mathrm{H}(3)$ is also supported, which means that individuals are more willing to purchase a product that carries both "no animal cruelty" certification and "no child labour" certification. The study shows that consumers have the highest intention to buy the product at a premium price when both the certificates are present. Scholars argued that having more than one certification may not increase an individual's purchase intention (Didier \& Lucie, 2008). On the other hand, scholars found that having two ethical certifications may increase the overall purchase intention of a product for an individual (Perrini et al., 2010). Thereby, this study helps in demystifying the contradictory literature present till now. The increase in willingness to pay a premium when both certificates are present may be because the consumer starts trusting the product more (Eldesouky et al., 2020). Future researchers may test whether two certifications develop consumer trust towards the product.

$\mathrm{H}(4)$ results indicate that the consumers prefer a shirt sold at the premium price over a soap sold at a premium price when the products are certified for "no animal cruelty." Contrary to the popular belief that "no animal cruelty" certification will be considered for cosmetics (Cornish et al., 2020; Silva et al., 2021) more than other product categories, this study found that individuals consider a shirt over soap. While limited literature is available that tests consumers reaction towards the same ethical certification for different products, scholars imply that consumer support of a moral issue may vary across product types (Han \& Stoel, 2016). A recent study shows that pro-social individuals demonstrate a concern for animal welfare (Achabou et al., 2020). Hence, this finding's probable reason is that "no animal cruelty" has become a recent trend. By wearing a shirt that most people see, consumers portray themselves as a part of the larger group supporting animal welfare.

The participants report that they prefer soap over a shirt for "no child labour" certified products. However, the difference between the two product involvement types is not significant. Hence, $\mathrm{H}(5)$ is not supported. Despite the non-significant relationship, it is interesting to foresee the probable reason for consumers preferring soap over a shirt while considering "no child labour" certifications. Despite the Government of India regulation that child labour is banned in chemical factory or in soap manufacturing units (Press Information Bureau, April 2012), the children are employed in various hazardous conditions in India, which may even prove fatal to them (Indian Express, November 2020). Additionally, the loopholes in the Child Labour (Prohibition and Regulation) Amendment Act, 2016, does not ensure that the children cannot be employed in chemical mixing units, for instance (The Hindu, August 2016). Since it is on top of the mind of the consumers that soap manufacturing requires handling of hazardous chemicals by the employees, the respondents have preferred to buy a soap with the "no child labour" certification over a shirt with "no child labour" certification. 
$\mathrm{H}$ (6) is also not supported in this study, as there is no significant interaction between product involvement and "no child labour" certification and "no animal cruelty" certification. These results show that even while buying a non-involving product such as a bar of soap, a consumer automatically reports higher intention to purchase the product at price premiums when both "no animal cruelty" certification and "no child labour" certification are present. The reaction to two certifications across involvement types is a good sign for marketers and a society that seeks equal and just treatment for everyone, including the weak and less powerful.

\subsection{Theoretical implications}

This study provides various theoretical implications. First, this study adds to the limited literature that examines consumers purchasing intentions for a product having multiple ethical certifications. Contrary to previous research that has taken broad certifications, such as fair trade, this study considers specific ethical certifications, such as no animal cruelty and no child labour. We say fair trade certification as broad because it encompasses various ethical features, such as environmental safety, labour safety, and animal protection. Thereby, it becomes difficult to examine how a single ethical issue impacts consumers propensity to purchase a product. In this research, we include specific ethical dimensions of no animal cruelty and no child labour, thereby, providing directions about consumers propensity to purchase products having these specific ethical properties.

Second, previous studies mainly consider a single product category while assessing consumer willingness to purchase a product at a price premium. The most popular product in previous studies is coffee. In this research, we extend the previous literature by examining two product involvement types across two product categories, which are clothing (shirt) and cosmetics (soap). We found that while both certifications are preferred for both product involvement types, the individual certifications preferred varies across product involvement types.

Third, this study includes the real price premiums in the market and helps examine reaction of consumers to these real price premiums. This approach is closer to the market scenario and provides directions regarding consumer willingness to purchase a product at real market price premiums.

Last, limited literature exists in the Indian context that examines consumers propensity to purchase an ethical product. This research adds to the literature in an emerging market context. We believe that this research may act as a catalyst for more studies regarding ethical consumption in an emerging market context.

\subsection{Implications for managers and practitioners}

Managers and practitioners can benefit from this study in several ways. First, the findings of the study reveal that consumer willingness to purchase a product at a price premium increases with the introduction of ethical certifications. 
The results show that consumers prefer the product in which both certifications of no animal cruelty and no child labour are present. Furthermore, among the two ethical certifications no animal cruelty is preferred over no child labour in case of a shirt and vice-versa in case of a bar of soap. The results imply that marketers should provide more than one ethical certification in their products for increasing consumer propensity to choose their products at a price premium. Furthermore, if marketers aim to cater to one ethical aspect then it would be more profitable to have no animal cruelty certification in case of a shirt and have no child labour certification in case of a bar of soap. Note that, possessing these certifications imply huge costs for the practitioners. Thereby, government and policy makers can design favourable policies by providing subsidies to companies which follow strict ethical standards for obtaining these certifications.

Additionally, the findings reveal that both high-involvement and low-involvement products are viewed by consumers in a positive light when they possess ethical certifications. Thereby, marketers need not focus on specific products for applying ethical certifications, but can provide these certifications across their product line. This may help marketers to gain a positive reputation in the consumer's mind as well as gain consumer's acceptance of their products.

\section{Limitations and future research}

The present research seeks to address the issue of low sales of ethical products by examining how individuals process product information (both ethical certification and product involvement types information). No research can be fully accurate, and this research too has certain limitations. The limitations are presented below.

First, the research has been done through a quantitative survey by presenting information of product scenarios to respondents. The survey approach can lead to various issues, such as social desirability bias and clarity of the questionnaire. Authors tried to minimize these issues by performing a pilot study, randomizing the product scenarios and ensuring privacy to the respondents. Researchers can test the individual's processing of product information in a real retail setting, where one can examine consumers reception and processing of information due to the presence of other external cues, such as other consumers, salesmen and advertisements.

Second, one can argue that these relationships may differ for different product categories. Although this study has included two product categories and found similar results for both the product categories, there may be certain product categories which may present different results. Researchers may test these relationships for more product categories. The results that come up by examining more product categories can highlight the similarities and differences that may emerge in consumer choice.

Third, researchers can introduce mediators, such as consumer trust and emotions to fully understand the boundary conditions under which the product information gets converted to purchasing intentions. The results may also vary with different socio-demographics. In general, it is shown that females are more ethical in their behaviour than men. Similarly, ethical product consumption is associated 
with higher-education and higher-income people. Socio-demographics can be used as moderators to check the differences in the relationships.

Last, emerging markets have shown that they focus more on economic benefits than environmental issues. In industrialized economies, there is more awareness regarding ethical and environmental issues. Researchers can perform a cross-cultural study to examine the differences in an individual's processing of product and ethical information across cultures.

Funding Open access funding provided by University of Agder.

Open Access This article is licensed under a Creative Commons Attribution 4.0 International License, which permits use, sharing, adaptation, distribution and reproduction in any medium or format, as long as you give appropriate credit to the original author(s) and the source, provide a link to the Creative Commons licence, and indicate if changes were made. The images or other third party material in this article are included in the article's Creative Commons licence, unless indicated otherwise in a credit line to the material. If material is not included in the article's Creative Commons licence and your intended use is not permitted by statutory regulation or exceeds the permitted use, you will need to obtain permission directly from the copyright holder. To view a copy of this licence, visit http://creativecommons.org/licen ses/by/4.0/.

\section{References}

Accenture (2020). COVID-19 Increasing Consumers' Focus on "Ethical Consumption," Accenture Survey Finds. Available at: https://newsroom.accenture.com/news/covid-19-increasing-consu mers-focus-on-ethical-consumption-accenture-survey-finds.htm. Accessed 23 June 2020.

Achabou, M. A., Dekhili, S., \& Codini, A. P. (2020). Consumer preferences towards animal-friendly fashion products: an application to the Italian market. Journal of Consumer Marketing, 37(6), 661-673.

Ajzen, I. (1991). The theory of planned behavior. Organizational Behavior and Human Decision Processes, 50(2), 179-211.

Alonso, M. E., González-Montaña, J. R., \& Lomillos, J. M. (2020). Consumers' concerns and perceptions of farm animal welfare. Animals, 10(3), 385.

Araque-Padilla, R. A., Montero-Simó, M. J., Rivera-Torres, P., \& Aragón-Gutiérrez, C. (2015). Moderating the relationship between price and perceived value of ethical products. Journal of Agricultural and Environmental Ethics, 28(2), 217-230.

Auger, P., \& Devinney, T. M. (2007). Do what consumers say matter? The misalignment of preferences with unconstrained ethical intentions. Journal of Business Ethics, 76(4), 361-383.

Baland, J. M., \& Duprez, C. (2009). Are labels effective against child labor? Journal of Public Economics, 93(11-12), 1125-1130.

Bandyopadhyay, C., \& Ray, S. (2020). Finding the sweet spot between ethics and aesthetics: A social entrepreneurial perspective to sustainable fashion brand (Juxta) positioning. Journal of Global Marketing, 33(5), 377-395.

Basgoze, P. N. (2012). Ethical perceptions and green buying behavior of consumers: a cross-national exploratory study. Journal of Economics and Behavioral Studies, 4(8), 477-488.

Belanche, D., Flavián, C., \& Pérez-Rueda, A. (2017). Understanding interactive online advertising: Congruence and product involvement in highly and lowly arousing, skippable video ads. Journal of Interactive Marketing, 37, 75-88.

Bennett, E. A. (2018). Extending ethical consumerism theory to semi-legal sectors: insights from recreational cannabis. Agriculture and Human Values, 35(2), 295-317.

Bian, X., \& Moutinho, L. (2011). The role of brand image, product involvement, and knowledge in explaining consumer purchase behaviour of counterfeits: direct and indirect effects. European Journal of Marketing, 45(1/2), 191-216. 
Bissinger, K., \& Leufkens, D. (2017). Ethical food labels in consumer preferences. British Food Journal, 119(8), 1801-1814.

Boje, D. M., \& Khan, F. R. (2009). Story-branding by empire entrepreneurs: Nike, child labour, and Pakistan's soccer ball industry. Journal of Small Business \& Entrepreneurship, 22(1), 9-24.

Boström, M., \& Micheletti, M. (2016). Introducing the sustainability challenge of textiles and clothing. Journal of Consumer Policy, 39(4), 367-375.

Cembalo, L., Caracciolo, F., Lombardi, A., Del Giudice, T., Grunert, K. G., \& Cicia, G. (2016). Determinants of individual attitudes toward animal welfare-friendly food products. Journal of Agricultural and Environmental Ethics, 29(2), 237-254.

Chun, R. (2016). What holds ethical consumers to a cosmetics brand: The Body Shop case. Business \& Society, 55(4), 528-549.

Clark, B., Stewart, G. B., Panzone, L. A., Kyriazakis, I., \& Frewer, L. J. (2017). Citizens, consumers and farm animal welfare: A meta-analysis of willingness-to-pay studies. Food Policy, 68, $112-127$.

Cornish, A. R., Briley, D., Wilson, B. J., Raubenheimer, D., Schlosberg, D., \& McGreevy, P. D. (2020). The price of good welfare: Does informing consumers about what on-package labels mean for animal welfare influence their purchase intentions? Appetite, 148, 104577.

Cosmina, M., Gallenti, G., Marangon, F., \& Troiano, S. (2016). Consumers preferences for ethical attributes of coffee: a choice experiment in the Italian market. Italian Review of Agricultural Economics, 71(1), 314-324.

Cottingham, J. (1978). 'A Brute to the Brutes?': Descartes' Treatment of Animals. Philosophy, 53(206), 551-559.

Cowan, K., \& Ketron, S. (2019). A dual model of product involvement for effective virtual reality: The roles of imagination, co-creation, telepresence, and interactivity. Journal of Business Research, 100, 483-492.

Dahlbo, H., Aalto, K., Eskelinen, H., \& Salmenperä, H. (2017). Increasing textile circulationconsequences and requirements. Sustainable Production and Consumption, 9, 44-57.

Davies, I. A., \& Gutsche, S. (2016). Consumer motivations for mainstream 'ethical' consumption. European Journal of Marketing, 50(7/8), 1326-1347.

Dholakia, U. M. (1998). Involvement-response models of joint effects: an empirical test and extension. Advances in Consumer Research, 25(1), 499-506.

Di Benedetto, C. A. (2017). Corporate social responsibility as an emerging business model in fashion marketing. Journal of Global Fashion Marketing, 8(4), 251-265.

Didier, T., \& Lucie, S. (2008). Measuring consumer's willingness to pay for organic and Fair Trade products. International Journal of Consumer Studies, 32(5), 479-490.

Dransfield, E., Ngapo, T. M., Nielsen, N. A., Bredahl, L., Sjödén, P. O., Magnusson, M., et al. (2005). Consumer choice and suggested price for pork as influenced by its appearance, taste and information concerning country of origin and organic pig production. Meat Science, 69, 61-70.

Ratna Bhushan (2019). Available at: https://economictimes.indiatimes.com/industry/cons-products/fmcg/ call-it-natural-ethical-or-green-to-sell-it-in-india/articleshow/71830503.cms?from=mdr. Accessed 18 July 2020.

Economic Times (2020). https://economictimes.indiatimes.com/news/economy/indicators/india-now-5thlargest-economy-globally-sitharaman/articleshow/73831787.cms. Accessed 2 Feb 2020.

Eldesouky, A., Mesias, F. J., \& Escribano, M. (2020). Perception of Spanish consumers towards environmentally friendly labelling in food. International Journal of Consumer Studies, 44(1), 64-76.

Erdenk, E. A. (2013). Descartes' account of feeling of pain in animals. FLSF, 201-210.

European Commission (2005). Attitudes of consumers towards the welfare of farmed animals. Special Eurobarometer 229, Wave 63.2.TNS Opinion and Social. Accessed Through: http://ec.europa.eu/ public_opinion/archives/ebs/ebs_229_en.pdf

Folkes, V. S., \& Kamins, M. A. (1999). Effects of information about firms' ethical and unethical actions on consumers attitudes. Journal of Consumer Psychology, 8(3), 243-259.

Foti, L., \& Devine, A. (2019). High involvement and ethical consumption: a study of the environmentally certified home purchase decision. Sustainability, 11(19), 5353.

Gadhavi, P., \& Sahni, H. (2020). Analyzing the "mindfulness" of young indian consumers in their fashion consumption. Journal of Global Marketing, 1-13.

Gallenti, G., Troiano, S., Cosmina, M., \& Marangon, F. (2016). Ethical and sustainable consumption in the Italian coffee market: A choice experiment to analyse consumers willingness to pay. Italian Review of Agricultural Economics, 71(2), 153-176. 
Gleim, M. R., Smith, J. S., Andrews, D., \& Cronin, J. J., Jr. (2013). Against the green: A multi-method examination of the barriers to green consumption. Journal of Retailing, 89(1), 44-61.

Gonzales R. (2019). Accessed Through: https://www.npr.org/2019/11/25/782842651/trump-signs-lawmaking-cruelty-to-animals-a-federal-crime. Accessed 29 June 2020.

Govind, R., Singh, J. J., Garg, N., \& D'Silva, S. (2019). Not walking the walk: how dual attitudes influence behavioral outcomes in ethical consumption. Journal of Business Ethics, 155(4), 1195-1214.

Hainmueller, J., \& Hiscox, M. J. (2015). The socially conscious consumer? Field experimental tests of consumer support for fair labor standards. Working paper, Harvard University, Boston.

Hainmueller, J., Hiscox, M. J., \& Sequeira, S. (2015). Consumer demand for fair trade: Evidence from a multistore field experiment. Review of Economics and Statistics, 97(2), 242-256.

Han, T. I., \& Stoel, L. (2016). The effect of social norms and product knowledge on purchase of organic cotton and fair-trade apparel. Journal of Global Fashion Marketing, 7(2), 89-102

Henninger, C. E., Alevizou, P. J., \& Oates, C. J. (2016). What is sustainable fashion? Journal of Fashion Marketing and Management: An International Journal, 20(4), 400-416.

Houston, M. J., \& Rothschild, L. M. (1978). "A Paradigm for Research on Consumer Involvement," Working Paper No. 11-77-46, University of Wisconsin, Madison.

Ilyas, A., Shahid, M. S., \& Hassan, R. A. (2020). Evaluating the motives of child labourers in the informal economy. International Journal of Sociology and Social Policy, 40(3/4), 409-424.

International Labor Organization (2018). Ending child labour by 2025: A review of policies and programmes. Second Edition. Available at: https://www.ilo.org/ipec/Informationresources/WCMS_ 653987/lang--en/index.htm. Accessed 22 Mar 2021.

International Labor Rights Forum (2011). Accessed Through: https://laborrights.org/blog/201109/ developmental-effects-child-labor. Accessed 23 May 2020.

Jung, H. J., Kim, H., \& Oh, K. W. (2016). Green leather for ethical consumers in China and Korea: Facilitating ethical consumption with value-belief-attitude logic. Journal of Business Ethics, 135(3), 483-502.

Kalyvas, H., Andra, S. S., Charisiadis, P., Karaolis, C., \& Makris, K. C. (2014). Influence of household cleaning practices on the magnitude and variability of urinary monochlorinated bisphenol A. Science of the Total Environment, 490, 254-261.

Kang, J. W., \& Namkung, Y. (2018). The effect of corporate social responsibility on brand equity and the moderating role of ethical consumerism: The case of Starbucks. Journal of Hospitality \& Tourism Research, 42(7), 1130-1151

Kassarjian, H. H. (1981). Low involvement-a second look. In Monroe K. B. (ed.) Advances in consumer research, Vol. 8. Ann Arbor, MI: Association for Consumer Research, pp 31-34.

Kennedy, A. G. (2019). Understanding child labor in Myanmar. Journal of Global Ethics, 15(3), $202-212$.

Konuk, F. A. (2019). Consumers willingness to buy and willingness to pay for fair trade food: The influence of consciousness for fair consumption, environmental concern, trust and innovativeness. Food Research International, 120, 141-147.

Kushwah, S., Dhir, A., \& Sagar, M. (2019). Ethical consumption intentions and choice behavior towards organic food. Moderation role of buying and environmental concerns. Journal of Cleaner Production, 236, 117519.

Lappeman, J., Orpwood, T., Russell, M., Zeller, T., \& Jansson, J. (2019). Personal values and willingness to pay for fair trade coffee in Cape Town, South Africa. Journal of Cleaner Production, 239, 118012.

Laurent, G., \& Kapferer, J. N. (1985). Measuring consumer involvement profiles. Journal of Marketing Research, 22(1), 41-53.

Lertwannawit, A., \& Mandhachitara, R. (2012). Interpersonal effects on fashion consciousness and status consumption moderated by materialism in metropolitan men. Journal of Business Research, 65(10), 1408-1416.

Lim, J. S., \& Shim, K. (2019). Corporate social responsibility beyond borders: US consumer boycotts of a global company over sweatshop issues in supplier factories overseas. American Behavioral Scientist, 63(12), 1643-1664.

Loureiro, M. L., \& Lotade, J. (2005). Do fair trade and eco-labels in coffee wake up the consumer conscience? Ecological Economics, 53(1), 129-138.

Lu, F. C., \& Sinha, J. (2019). Dichotomous thinking and ethical consumerism: overcoming the negative effects of self-interest bias through third-person narrative persuasion. Journal of Advertising, $48(3), 271-283$. 
Maaya, L., Meulders, M., Surmont, N., \& Vandebroek, M. (2018). Effect of environmental and altruistic attitudes on willingness-to-pay for organic and fair trade coffee in Flanders. Sustainability, 10(12), 4496.

Mai, L.-W. (2014). Consumers willingness to pay for ethical attributes. Marketing Intelligence and Planning, 32(6), 706-721.

Makarem, S. C., \& Jae, H. (2016). Consumer boycott behavior: An exploratory analysis of twitter feeds. Journal of Consumer Affairs, 50(1), 193-223.

Maya Jariego, I. (2017). "But we want to work": The movement of child workers in Peru and the actions for reducing child labor. American Journal of Community Psychology, 60(3-4), 430-438.

Minton, E., Lee, C., Orth, U., Kim, C. H., \& Kahle, L. (2012). Sustainable marketing and social media: a cross-country analysis of motives for sustainable behaviors. Journal of Advertising, 41(4), 69-84.

Miranda-de la Lama, G. C., Estévez-Moreno, L. X., Villarroel, M., Rayas-Amor, A. A., María, G. A., \& Sepúlveda, W. S. (2019). Consumer attitudes toward animal welfare-friendly products and willingness to pay: Exploration of Mexican market segments. Journal of Applied Animal Welfare Science, 22(1), 13-25.

Mittal, B. (1989). Measuring purchase-decision involvement. Psychology \& Marketing, 6, 147-163.

Mittal, B. (1995). A comparative analysis of four scales of involvement. Psychology \& Marketing, 12, $663-682$.

Mittal, B., \& Myung-Soo, L. (1988). Separating brand-choice involvement from product involvement via consumer involvement profiles. In Houston M.J (ed.), Provo, UT: Association for Consumer Research in Advances in Consumer Research, 15, 43-46.

Napolitano, F., Girolami, A., \& Braghieri, A. (2010). Consumer liking and willingness to pay for high welfare animal-based products. Trends in Food Science \& Technology, 21(11), 537-543.

Nuttavuthisit, K., \& Thøgersen, J. (2017). The importance of consumer trust for the emergence of a market for green products: The case of organic food. Journal of Business Ethics, 140(2), 323-337.

Park, K. C. (2018). Understanding ethical consumers: willingness-to-pay by moral cause. Journal of Consumer Marketing., 35(2), 157-168.

Peattie, K., \& Samuel, A. (2018). Fairtrade towns as unconventional networks of ethical activism. Journal of Business Ethics, 153(1), 265-282.

Perrini, F., Castaldo, S., Misani, N., \& Tencati, A. (2010). The impact of corporate social responsibility associations on trust in organic products marketed by mainstream retailers: a study of Italian consumers. Business Strategy and the Environment, 19(8), 512-526.

Press Information Bureau (2012). Industries where Employing Child Labour is banned. Available at: https://pib.gov.in/newsite/PrintRelease.aspx?relid=82630. Accessed 22 Mar 2021.

Rashid, M. S., \& Byun, S. E. (2018). Are consumers willing to go the extra mile for fair trade products made in a developing country? A comparison with made in USA products at different prices. Journal of Retailing and Consumer Services, 41, 201-210.

Retail News Asia (2019). The Body Shop India to open 20 new stores in 2019. Available at: https://www. retailnews.asia/the-body-shop-india-to-open-20-new-stores-in-2019/. Accessed 22 Mar 2021.

Roloff, L. Y. (2018). Want a fairer fashion industry? This is what you can do https://www.greenpeace.org/ international/story/16087/want-a-fairer-fashion-industry-thisis-what-you-can-do/

Rousseau, S. (2015). The role of organic and fair trade labels when choosing chocolate. 527 food quality and preference, 44, 92-100.

Ryan, J., \& Casidy, R. (2018). The role of brand reputation in organic food consumption: A behavioral reasoning perspective. Journal of Retailing and Consumer Services, 41, 239-247.

Schuitema, G., \& De Groot, J. I. (2015). Green consumerism: The influence of product attributes and values on purchasing intentions. Journal of Consumer Behaviour, 14(1), 57-69.

Sherif, M., \& Cantril, H. (1947). The psychology of ego-involvements: Social attitudes and identifications. Wiley.

Silva, A., Fonseca, M. J., Cardoso, P. R., Fonseca, M. C., \& Teixeira, A. (2021). Factors influencing the purchase intention of cruelty-free cosmetics in Portuguese consumers-an exploratory approach. In International Conference on Information Technology \& Systems, 256-268. Springer, Cham.

Simangunsong, E., Hendry, L. C., \& Stevenson, M. (2016). Managing supply chain uncertainty with emerging ethical issues. International Journal of Operations \& Production Management, 36(10), 1272-1307.

Smestad, L. (2009). The sweatshop, child labor, and exploitation issues in the garment industry. Fashion Practice, 1(2), 147-162.

Smith, A. (2019). The Wealth of Nations. Courier Dover Publications. 
Sreen, N., Purbey, S., \& Sadarangani, P. (2018). Impact of culture, behavior and gender on green purchase intention. Journal of Retailing and Consumer Services, 41, 177-189.

Swanson, J. C., \& Mench, J. A. (2000). Animal welfare: Consumer viewpoints. In. (2000). Poultry Symposium and Egg Processing Workshop. University of California.

Taplin, I. M. (2014). Who is to blame?: A re-examination of fast fashion after the 2013 factory disaster in Bangladesh. Critical Perspectives on International Business, 10(1-2), 72-83.

Tarkiainen, A., \& Sundqvist, S. (2009). Product involvement in organic food consumption: does ideology meet practice? Psychology \& Marketing, 26(9), 844-863.

The Hindu (2016). A law that allows child labour. Available at: https://www.thehindu.com/opinion/columns/Alaw-that-allows-child-labour/article14560563.ece. Accessed 22 March 2021.

The Indian Express (2020). Ahmedabad: Factory violated child labour laws, stocked explosive materials, says report. Available at: https://indianexpress.com/article/cities/ahmedabad/ahmedabad-factoryviolated-child-labour-laws-stocked-explosive-materials-says-report/. Accessed 22 Mar 2021.

Unilever (2017). Report shows a third of consumers prefer sustainable brands. Available at: https://www. Unilever.Com/News/Press-Releases/2017/Report-Shows-A-Third-of-Consumers-Prefer-Sustainable-Brands.Html. Accessed 12 June 2020.

Vehmas, K., Raudaskoski, A., \& Heikkil€a, P., Harlin, A., \& Mensonen, A. . (2018). Consumer attitudes and communication in circular fashion. Journal of Fashion Marketing and Management: An International Journal, 22(3), 286-300.

Wang, L., Wang, J., \& Huo, X. (2019). Consumer's willingness to pay a premium for organic fruits in China: a double-hurdle analysis. International Journal of Environmental Research and Public Health, 16(1), 126.

Wiederhold, M., \& Martinez, L. F. (2018). Ethical consumer behaviour in Germany: The attitude-behaviour gap in the green apparel industry. International Journal of Consumer Studies, 42(4), 419-429.

Yacout, O. M., \& Vitell, S. (2018). Ethical consumer decision-making: The role of need for cognition and affective responses. Business Ethics: A European Review, 27(2), 178-194.

Yao, R. T., Langer, E. R., Leckie, A., \& Tremblay, L. A. (2019). Household preferences when purchasing handwashing liquid soap: A choice experiment application. Journal of Cleaner Production, 235, $1515-1524$.

Yuvraj (2020). \#NoMore50: Activists are rising to demand harsher punishments for cruelty to animals. Accessed Through: https://scroll.in/article/808148/nomore50-why-animal-lovers-are-rising-to-demandharsher-punishments-for-cruelty-to-animals. Accessed 29 June 2020.

Zaichkowsky, J. L. (1985). Measuring the involvement construct. Journal of Consumer Research, 12(3), 341-352.

Publisher's Note Springer Nature remains neutral with regard to jurisdictional claims in published maps and institutional affiliations. 


\section{Authors and Affiliations}

\section{Swetarupa Chatterjee ${ }^{1} \cdot$ Naman Sreen $^{2,3}$ (D) Jyoti Rana ${ }^{4} \cdot$ Amandeep Dhir $^{5,6,7}$. Pradip H. Sadarangani ${ }^{1}$}

Swetarupa Chatterjee

swetarupa.fpm17@iimshillong.ac.in

Naman Sreen

naman.sreen@iimrohtak.ac.in

Jyoti Rana

jyoti.rana@svsu.ac.in

Pradip H. Sadarangani

ps@iimshillong.ac.in

1 Indian Institute of Management Shillong, Shillong-793014, Nongthymmai, India

2 Jindal Global Business School, Jindal Global University, Near Jagdishpur Village, Sonipat Narela Road, Sonipat Haryana- 131001, India

3 Indian Institute of Management Rohtak, Management City, Southern Bypass, Sunaria, Rohtak, Haryana 124010, India

4 Dean, Skill Faculty of Management Studies, Shri Vishwakarma Skill University, Haryana-121002, Palwal, India

5 Department of Management, School of Business \& Law, University of Agder, Kristiansand, Norway

6 Norwegian School of Hotel Management, Faculty of Social Sciences, Stavanger, Norway

7 Optentia Research Focus Area, North-West University, Vanderbijlpark, South Africa 